\title{
A Study of Hong Kong Tax Compliance Ethics
}

\author{
Daniel Ho \\ Department of Accountancy \& Law, School of Business, Hong Kong Baptist University \\ Kowloon Tong, Hong Kong \\ Tel: 852-3411-7539 E-mail: danielho@hkbu.edu.hk
}

Brossa Wong (Corresponding author)

Accounting Department, Hang Seng School of Commerce

Shatin, Hong Kong

Tel: 852-2636-7173 E-mail: brossawong@hssc.edu.hk

\begin{abstract}
This paper extends our previous study by discussing in more details the composition and functions of the Board of Review in Hong Kong. We conduct a trend analysis on the Board's decisions by examining three recent informal tax cases relating to compliance behavior for individual taxpayers in Hong Kong. We find that the more recent Board's decisions are quite consistent with our previous findings. The level of penalty tax levied increases with the intention of the taxpayers to avoid tax, the magnitude of tax undercharged and the poor attitude of taxpayers. Despite the regular changes in the composition of the Board members, consistency in the Board's decisions may be explained by the following reasons: there is no change in principle or in spirit in making decisions, there is no new development in the penalty policy and the Board has been adopting the decisions of precedent Board cases in similar situations.
\end{abstract}

Keywords: Ethics, Tax compliance, Tax cases, Individual taxpayers, Hong Kong

\section{Introduction}

When faced with tax moral dilemmas, it is generally believed that ethics can serve as guidelines for taxpayers on how to act rightly and justly. To better understand the inter-relationship between ethics and tax compliance, we have conducted a study to perform an extensive literature review on them and to examine three informal tax cases relating to compliance behavior for individual taxpayers in Hong Kong. We noted that ethical beliefs could be an effective means to improve tax compliance, particularly for taxpayers with lower levels of moral development. In addition, tax compliance rate may be higher when taxpayer has a stronger moral belief that tax evasion is not ethical. More importantly, a stronger enforcement effort might have a positive overall effect on tax compliance. We therefore suggested the introduction of general ethics education for all citizens in Hong Kong in order to enhance level of moral development which in turn could improve tax compliance at large (Ho \& Wong, 2008).

An examination of the actions of taxpayers provides insightful information on tax compliance and ethics issues as "morality (ethics) ultimately lies in action and that the study of moral (ethical) development should use action as final criterion" (Blasi, 1980, p.1, italics words added). Since our last study, there are new penalty tax cases. We are motivated to explore into whether the decisions of the Board of Review (the Board), which is an independent statutory body to determine tax appeals, will be affected by different composition of members and / or if there is any change in principle or in spirit because of the passage of time. The purpose of this paper is to extend our previous study by discussing in more details the composition and functions of the Board in Hong Kong. In addition, we conduct a trend analysis on the Board's decisions by examining another three recent informal tax cases relating to compliance behavior for individual taxpayers in Hong Kong.

The remainder of this paper is organized as follows. The next section describes and discusses the composition and functions of the Board in Hong Kong. This is followed by a section which critically examines three informal tax cases related to compliance behavior of individual taxpayers in Hong Kong. The last section concludes this paper.

\section{Board of Review in Hong Kong}

\subsection{Introduction}

The Board of Review (Inland Revenue Ordinance) is an independent statutory body constituted under section 65 of the Inland Revenue Ordinance (the IRO) to determine tax appeals. The jurisdiction of the Board is stipulated in sections 66 to $69 \mathrm{~A}$ and section $82 \mathrm{~B}$ of the IRO. The Board consists of a chairman and ten deputy chairmen, who are persons with 
legal training and experience, and not more than 150 other members, all of whom are appointed by the Chief Executive of Hong Kong. The second author of this paper was appointed by the Chief Executive of the Hong Kong government as a member to the Board for a period of three years up to 31 December 2007.

\subsection{Functions and Procedures}

The Board is an independent tribunal and informal tax court in Hong Kong to determine tax appeals. Any taxpayer may lodge an appeal by giving notice of appeal in writing to the clerk to the Board (the clerk) under the following circumstances:

a. If a taxpayer has validly objected to an assessment but the Commissioner of Inland Revenue (the Commissioner) considered the objection has failed, the taxpayer may lodge an appeal to the Board within one month after the transmission of the Commissioner's written determination.

b. The IRO empowers the Commissioner to institute prosecution, to compound or to assess additional penalty tax if taxpayers fail to comply with the requirements under the IRO. For less serious cases, i.e. offences that do not involve any willful intent to evade tax, they are generally dealt with administratively by the imposition of additional penalty tax under section $82 \mathrm{~A}$ of the IRO. A taxpayer who has been assessed an additional penalty tax can appeal to the Board under section 82B of the IRO within one month after the date of issue of the notice of assessment.

\subsection{Composition and Functions of the Hearing Panel}

On receipt of a notice of appeal, the clerk will fix a time for the hearing of the appeal. A hearing panel with at least three members, one of whom is either the chairman or a deputy chairman, is formed to determine the tax appeal. The chairman or the deputy chairman will serve as the panel chair and two other members will serve as panel members. All members to the Board are provided with a schedule of hearings on a monthly basis and it is voluntary for members to sign up as a panel member for the hearing. The second author has heard two hearings as a panel member during her term. Decision is made on the basis of a majority of votes, and in the case of an equality of votes the chairman or deputy chairman, i.e. the panel chair, will have a second or casting vote.

\subsection{Attending Board of Review Hearing}

A taxpayer should attend the hearing of an appeal either in person or by an authorized representative. The Board may proceed to hear the appeal in the absence of the taxpayer and his authorized representative under special circumstances. In such case, the Board may consider the written submissions of the taxpayer.

All appeals are heard in camera. The onus of proving that the assessment appealed against is excessive or incorrect is on the taxpayer. The taxpayer should therefore call upon all witnesses and place all documents, no less than 14 days before the hearing, to support his appeal. The taxpayer is given a choice at the hearing of either making an unsworn statement or giving evidence on oath in support of the appeal. The taxpayer will be cross examined by representative of the Commissioner if he chooses the latter option and greater weight will be attached to evidence tested by such process.

After hearing the appeal, the Board will confirm, reduce, increase or annul the assessment appealed against or may remit the case to the Commissioner for re-assessment. The Board may also order the taxpayer to pay as costs of the Board an additional sum not exceeding HK\$5 000, if the proceeding has been conducted frivolously, vexatiously or an abuse of process.

\subsection{Delivery of Board of Review Decisions}

The decision of the Board is final; however either the taxpayer or the Commissioner may make an application requiring the Board to state a case on a question of law for the opinion of the Court of First Instance, within one month of the date of the Board's decision. After hearing an appeal, the panel chairman will deliver the decision of the Board which is normally in written form. The panel chairman is responsible to report the case which is endorsed by panel members. The Board of Review Decisions, available on-line and in printed version, is a publication of the Board which contains selected decisions on tax appeals written by the presiding chairmen (and endorsed by panel members) of hearings. In accordance with section 68(5) of the IRO, the identity of the taxpayer is not disclosed.

\section{Trend Analysis on Real-life Perspectives}

In our previous study (Ho \& Wong, 2008), we have examined three informal tax cases relating to compliance behavior for individual taxpayers in Hong Kong. All the taxpayers in these cases have committed behavior of understating or omission of income. Since our last analysis, there are new penalty tax cases. As the term of each appointed member to the Board is three years, there is a consistent change in the composition of the Board. Moreover, the penal of each hearing is randomly formed by voluntary members. We are therefore motivated to explore into whether the decision of the Board will be affected by different composition of members and / or if there is any change in principle or in spirit because of the passage of time. As such, we extend our previous study to examine another three recent informal tax cases relating to compliance behavior for individual taxpayers in Hong Kong and to conduct a trend analysis on the 
Board's decisions.

\subsection{The Cases}

\subsubsection{Case One}

Case D4/06 (2006-07, Volume 21) was heard on 25 February 2006 and the decision was delivered on 10 April 2006. The hearing panel composed of Mr. Kenneth Kwok Hing Wai SC (chairman), Mr. David Li Ka Fai and Mr. Horace Wong Ho Ming.

The taxpayer was a computer systems specialist and she applied for business registration as sole proprietress of a business (the Firm) on 23 June 2000. On the same date, she signed a 'Professional Services Contract General Agreement' in the name of the Firm with a bank (the Bank) under which the Firm would provide services in the capacity of a Systems Specialist for around one year for a fee of HK\$547 560. The agreement also provided that the Firm would assign the taxpayer to provide the services. The business registration records of the Firm were changed on 4 October 2000 and the taxpayer's father, who was unemployed, was added as a partner of the Firm with effect from 1 September 2000.

The taxpayer did not report the fees paid by the Bank as her salary income but reported income as a partner of the Firm with a $10 \%$ share of the profits, while her father was said to have a share of the remaining profits. The Revenue conducted an audit on the taxpayer's affairs on 21 January 2005 and the taxpayer reached compromise with the Revenue on 26 February 2005. She agreed to the amounts of understated income for the years of assessment 2000/01 and 2001/02 and the understated income was computed on the basis that the fees paid by the Bank were the taxpayer's salary income. Two additional assessments were then issued in accordance with the compromise document and the taxpayer did not object to the assessments. The document also provided that penal actions may be considered by the Revenue.

The Deputy Commissioner subsequently issued two penalty assessments to assess the taxpayer to additional tax under section $82 \mathrm{~A}$ of the IRO. The additional tax imposed averaged $68 \%$ of the tax undercharged. The taxpayer appealed to the Board on the grounds that she was not liable to additional tax and that the amount of additional tax was excessive. The taxpayer contended that she was compelled by the Bank to contract as a contractor instead of an employee. She had reported the fees paid by the Bank under profits tax because she did not know that she should report the fees as her salary. She also stated that there were about 30 persons in her team and that about seven to eight of them had contracts similar to her case.

The Board found that since more than two thirds of the persons in her team were employees, the taxpayer had failed to prove that she was compelled by the Bank to contract as a contractor instead of an employee. In the absence of compulsion by the Bank, the Board held that the taxpayer had no reasonable excuse to understate her salary income. The taxpayer had understated $81 \%$ and $38 \%$ of the correct amount of income for the years of assessment $2000 / 01$ and 2001/02 respectively. The understatement, although involving two years of assessment, was in respect of the fees from the Bank over a one-year period. The Board was impressed by the co-operation of the taxpayer and adopted the same approach as in case D90/01 (2001, Volume 16, Third Supplement) to reduce the additional tax imposed by half.

\subsubsection{Case Two}

Case D80/06 (2007-08, Volume 22) was heard on 24 November 2006 and the decision was delivered on 6 February 2007. The hearing panel composed of Mr. Kenneth Kwok Hing Wai SC (chairman), Mr. Ip Tak Keung and Ms. Susanna W Y Lee.

The taxpayer had understated his salary income by $29.04 \%$ in his tax return for the year of assessment $2004 / 05$. The assessor assessed the taxpayer to salaries tax based on the total amounts of income reported in the employers' returns and the taxpayer did not appeal against the assessment. The Deputy Commissioner subsequently issued a penalty assessment to assess the taxpayer to additional tax under section $82 \mathrm{~A}$ of the IRO. The additional tax imposed was HK\$4 400 , being $19.77 \%$ of the amount of tax undercharged.

The taxpayer appealed against the penalty assessment and claimed that he had understated his income because his employer failed to give correct notification to him regarding his remuneration. The Board was of the view that a taxpayer had the duty to report the correct amount of income. Receipt and accrual of income and the total amount thereof were factual matters within the personal knowledge of the taxpayer. One should have knowledge of his own total income and should not be spoon-fed by the employer.

The Board considered that the taxpayer should be able to verify the correctness of his income even though his emoluments were paid into his bank account by auto-pay. The Board held that the taxpayer was in reckless disregard of his duty to report the correct amount of his income and carelessness was not an excuse for submitting an incorrect return. The taxpayer held senior positions and the understatement of income was significant, both in amount and percentage. The Board held that payment of tax on time, lack of intention to evade tax and frequent change of jobs were 
not mitigating factors.

The taxpayer had also understated his income three years ago in his 2001/02 tax return but no additional tax had been imposed in that occasion. The Board was of the view that taxpayers should take their duty seriously and heavier penalty should be imposed for subsequent contraventions. The Board held that the additional tax for the year of assessment 2004/05 was not excessive and was much inclined to increase the additional tax. Instead of increasing the additional tax, a costs order of HK\$2 500 was made and the appeal was dismissed.

\subsubsection{Case Three}

Case D22/07 (2007-08, Volume 22, First Supplement) was heard on 16 August 2007 and the decision was delivered on 11 September 2007. The hearing panel composed of Mr. Kenneth Kwok Hing Wai SC (chairman), Mr. Donald Choi Wun Hing and Mr. David Kwok Sek Chi.

The taxpayer was employed by his former employer as the chief executive officer from 1 April 2005 to 31 October 2005 with a total salary income of HK\$1 225002 and his former employer reported the taxpayer's income to the Revenue. The taxpayer was also employed by another company in a part-time capacity with a salary income of HK\$857 500 for the period between 1 April 2005 and 31 March 2006. However, the taxpayer only reported his salary income from his part-time job in his tax return and omitted the income from his former employer. The assessor assessed the taxpayer to salaries tax based on the total amounts of income reported in the employers' returns and the taxpayer did not appeal against the salaries tax assessment. After considering representations made on behalf of the taxpayer, the Deputy Commissioner assessed the taxpayer to additional tax under section $82 \mathrm{~A}$ of the IRO which is equivalent to $8.16 \%$ of the tax undercharged.

The taxpayer appealed against the penalty assessment and contended that he accepted that it was his error and his fault. He impressed the Board that he had no intention to, and did not, deceive the Revenue. He left it to his wife to handle tax reporting but he had forgotten to provide his wife with his former employer's return and did not check the information on his tax return.

The Board, having considered all the matters urged by on behalf of the taxpayer, did not think that the assessment was excessive and the appeal was dismissed. The Board also decided not to increase the assessment for the following reasons. The taxpayer had taken and was taking steps to ensure further compliance. It was a mitigating factor for a taxpayer to put in place an effective system or mechanism to prevent any further contravention. The taxpayer had learnt a lesson and was sincere in his promise to comply with his reporting duties in future.

\subsection{The Analysis}

An interesting finding is that Mr. Kenneth Kwok Hing Wai SC served as panel chair for all the three recent cases and he is in fact the existing Chairman of the Board. In general, the decision of a taxpayer to behave unethically may be explained by the following factors: expected gain in tax savings from behaving unethically; low individual perception of the likelihood; low individual attitude to risk; and low individual ethical reasoning levels. Fischer et al. (1992) proposed a model of taxpayer compliance with four dimensions, namely demographic; non-compliance opportunity; attitude and perceptions; and tax system or structure. The Fisher model has been empirically tested by Chan et al. (2000). The taxpayers in these three cases have similar education level, income level and income source. They are all educated and occupy senior positions in their employment. All taxpayers in these cases have committed the same offence of understating or omission of income despite that their moral development, attitudes towards fairness of tax system, levels of non-compliance, and their attitude towards their tax affairs and tax authorities are quite different.

In case D22/07 (2007-08, Volume 22, First Supplement), the taxpayer had understated his salary income by 59\% due to his carelessness and the penalty tax imposed was only $8 \%$ of the tax undercharged. Carelessness was not an excuse for submitting an incorrect return. The Board did not think that the penalty tax assessment was excessive or insufficient. It was because the taxpayer has showed a good attitude and was sincere in his promise to comply with his reporting duties in future. It was a mitigating factor for a taxpayer to put in place an effective system or mechanism to prevent any further contravention.

In case D80/06 (2007-08, Volume 22), the taxpayer had understated his salary income by $29 \%$ but the penalty tax imposed was $19 \%$ of the tax undercharged. The Board held that the taxpayer was in reckless disregard of his duty to report the correct amount of his income and carelessness was not an excuse for submitting an incorrect return. His attitude did not convince the Board that he was serious with his tax affairs. The Board also held that payment of tax on time, lack of intention to evade tax and frequent change of jobs were not mitigating factors. The taxpayer had also understated his income three years ago and the Board was of the view that heavier penalty should be imposed for subsequent contraventions. Instead of increasing the additional tax, a costs order of HK $\$ 2,500$ was thus made.

In case D4/06 (2006-07, Volume 21), the taxpayer had adopted a tax evasion plan and was found to have understated her income as a result of tax investigation conducted by the Revenue. The taxpayer had understated $81 \%$ and $38 \%$ of 
the correct amount of income for two years of assessment. The understatement, although involving two years of assessment, was in respect of the fees from the Bank over a one-year period. The additional tax imposed averaged $68 \%$ of the tax undercharged. The Board was impressed by the co-operation of the taxpayer and adopted the same approach in a precedent case D90/01 (Volume 16, Third Supplement) to reduce the additional tax imposed by half.

In order to provide a comparison of the Board's decisions over time, the following summary of discussion of three cases $D 21 / 05, D 48 / 05$ and D59/05 are extracted from our previous paper (Ho \& Wong, 2008). The taxpayers in D21/05 (2005-06, Volume 20, First Supplement) are successful businessmen with low education level and they have understated substantial amount of income (nearly HK\$20M) for long duration of seven years. However, they were co-operative during the time of investigation and the final level of penalty was reduced from $150 \%$ to $120 \%$ and $140 \%$ of the respective tax undercharged. The taxpayer in D48/05 (2005-06, Volume 20, Second Supplement) is a practicing solicitor with high education level and he has omitted quite substantial amount of income (nearly HK\$2M) for four years. However, he is not serious with his tax affairs and as such has committed the offence and even missed the deadline for a valid appeal. The penalty level remains at about $50 \%$ of tax undercharged. The taxpayer in D59/05 (2005-06, Volume 20, Third Supplement) is a research manager with reasonable education level and has committed an error in understating his income. However, his attitude is very bad when being imposed of penalty tax at $7.86 \%$ of tax undercharged and the Board ordered him to pay an additional sum of HK\$5 000 given that the appeal is frivolous and vexatious.

It can be seen that the more recent Board's decisions are quite consistent with our previous findings. The level of penalty tax levied increases with the intention of the taxpayers to avoid tax, the magnitude of tax undercharged and the poor attitude of taxpayers. The decisions of the Board are consistent over the time framework we have studied despite the regular changes in the composition of the Board members. Consistency in the decisions demonstrates that there is no change in principle or in spirit in making decisions. In fact, there is no new development in the penalty policy adopted by the Revenue despite the passage of time. The consistency can be further explained by the fact that the Board has been adopting the decisions of precedent Board cases in similar situations.

\section{Conclusion}

The Board of Review is an independent statutory body constituted under the IRO to determine tax appeals in Hong Kong. Any taxpayer may lodge an appeal by giving notice of appeal in writing to the clerk to the Board if he disagrees with the determination of the Commissioner under an objection or with the level of penalty tax being imposed. A hearing panel with at least three members, one of whom is either the chairman or a deputy chairman, is formed to determine the tax appeal. Decision is made on the basis of a majority of votes. A taxpayer should attend the hearing of an appeal either in person or by an authorized representative. The onus of proving that the assessment appealed against is excessive or incorrect is on the taxpayer. After hearing the appeal, the Board will confirm, reduce, increase or annul the assessment appealed against or may remit the case to the Commissioner for re-assessment. The decision of the Board is final; however either the taxpayer or the Commissioner may make an application requiring the Board to state a case on a question of law for the opinion of the Court of First Instance, within one month of the date of the Board's decision.

As the term of each appointed member to the Board is three years, there is a consistent change in the composition of the Board. Moreover, the penal of each hearing is randomly formed by voluntary members. As an extension of our previous study, we conduct a trend analysis on the Board's decisions by examining another three recent informal tax cases relating to compliance behavior for individual taxpayers in Hong Kong. The more recent Board's decisions are quite consistent with our previous findings. The level of penalty tax levied increases with the intention of the taxpayers to avoid tax, the magnitude of tax undercharged and the poor attitude of taxpayers. Despite the regular changes in the composition of the Board members, consistency in the Board's decisions may be explained by the following reasons: there is no change in principle or in spirit in making decisions; there is no new development in the penalty policy; and the Board has been adopting the decisions of precedent Board cases in similar situations.

\section{References}

(2001). Case No. D90/01, Hong Kong Inland Revenue Board of Review Decisions, Volume 16, Third Supplement.

(2005-06). Case No. D21/05, Hong Kong Inland Revenue Board of Review Decisions, Volume 20, First Supplement, 346-357.

(2005-06). Case No. D48/05, Hong Kong Inland Revenue Board of Review Decisions, Volume 20, Second Supplement, 638-647.

(2005-06). Case No. D59/05, Hong Kong Inland Revenue Board of Review Decisions, Volume 20, Third Supplement, 821-827.

(2006-07). Case No. D04/06, Hong Kong Inland Revenue Board of Review Decisions, Volume 21, 139-146. 
(2007-08). Case No. D80/06, Hong Kong Inland Revenue Board of Review Decisions, Volume 22, 61-70.

(2007-08). Case No. D22/07, Hong Kong Inland Revenue Board of Review Decisions, Volume 22, First Supplement, 555-558

Blasi, A. (1980). Bridging Moral Cognition and Moral Action: A Critical Review of the Literature. Psychological Bulletin, 88(1), July, 1-45.

Chan, C. W., Troutman, C. S., \& O’Bryan D. (2000). An Expanded Model of Taxpayer Compliance: Empirical Evidence from the United States and Hong Kong. Journal of International Accounting, Auditing \& Taxation, 9 (2), 83-103.

Fischer, C. M., Wartick, M., \& Mark M. M. (1992). Detection Probability and Taxpayer Compliance: A Review of the Literature. Journal of Accounting Literature, 11, 1-46.

Ho, D., \& Wong, B. (2008). Issues on Compliance and Ethics in Taxation: What Do We Know? Journal of Financial Crime, 15 (4), 369-382. 